\title{
MOBILNI TELEFON IN POSPEŠENA KULTURA BREDA LUTHAR
}

\begin{abstract}
Povzetek
Članek obravnava možnosti objektne ali "protetične" obravnave telefona. Ugotavlja, da je proučevanja tele-

fona kot objekta, ki ga neprenehno nosimo s seboj, osredotočeno na njegov simbolni ali reprezentacijski vidik (kot objekt telefon metaforično reprezentira zunanjo realnost, torej kaže npr. na statusne ali generacijske razlike). Da bi razumeli kako sodobni "mobilni obrat" oblikuje strukturo

bolj osrediščena okoli objektov.
\end{abstract} Breda Luthar je izredna profesorica na Fakulteti za družbene vede Univerze v Ljubljani; e-pošta:

breda.luthar@fdv.uni-lj.si. 


\section{Uvod}

$\mathrm{V}$ primerjavi s stacionarnim telefonom, o katerem je bilo v več kot sto letih njegovega obstoja presenetljivo malo napisanega, je od leta 2002 dalje izšla množica člankov, tematskih revij, knjig in številnih zbornikov, ki se ukvarjajo z mobilnim telefonom. ${ }^{1}$ Članki in monografije se lotevajo vrste tematik, od generacijske in razredne dimenzije uporabe telefona, adaptacije telefona $\mathrm{v}$ različnih nacionalnih kontekstih glede na družbene in kulturne razlike, telefon in hiperkoordinacija, telefon in drugi novi mediji, telefon in nadzorovanje, domestifikacija in mobilna tehnologija, vprašanje razmerja med javnim in zasebnim $\mathrm{v}$ kontekstu uporabe mobilnega telefona, SMS-anje in ekonomija obdarovanja z SMS-i, telefon kot estetski in statusni objekt, moda in "lifestylizacija" telefona v promocijskih diskurzih, telefon in družbena omrežja itd.

Po pregledu literature smo dobili vtis, da kljub obilici publikacij manjka zares poglobljena komunikološka, sociološka ali antropološka analiza mobilnega telefona, ki bi tematizirala "mobilni obrat" v komuniciranju in posledice tega obrata za sodobno "strukturo občutenja" ter za razmerja moči in dominacije. Dva, na prvi pogled očitna vidika sodobne kulture, ki ju povezujemo z "naturalizacijo" uporabe mobilnega telefona v vsakdanjem življenju, sta ostala sicer tu in tam tematizirana, vendar bolj opisno in anekdotično kot teoretsko utemeljeno. Prvi zapostavljeni vidik je širša historična transformacija izkustva časa in imaginarnega odnosa do časa in $\mathrm{s}$ tem tudi prostora, prispevek mobilnega telefona skupaj z drugimi tehnologijami h kulturi hitrosti in "takojšnjosti" (Tomlinson 2007) ter ontološke in družbene posledice te transformacije v visokem kapitalizmu. Konkretizacije tega preoblikovanja lahko vidimo vsak dan in na svoji koži, najbolj očitno na področju kulture dela, kjer prihaja do izjemnega naraščanja instrumentalne delovne komunikacije, pa tudi pri preoblikovanju naše estetske percepcije. ${ }^{2}$

Drugi, prav tako očitni in hkrati zapostavljeni in podteoretizirani vidik mobilne telefonije je obravnava telefona kot stvari, artefakta. Čeprav smo naleteli na kar nekaj prispevkov, raziskav, poglavij o objektni naravi telefona, pa se te praviloma osredotočajo na simbolno, torej na diskurzivno funkcijo telefona kot reprezentanta družbenih razmerij, na primer kulturnih, razrednih ali generacijskih razlik, ne pa na družbeno vlogo telefona kot materialnega objekta, ki ga nenehoma prenašamo $\mathrm{s}$ sabo. Tu se bomo posvetili pregledu nekaterih argumentov, ki branijo obravnavo tehnoloških artefaktov kot materialnih stvari, objektov na račun njihove simbolne narave, in predstavili t. i. "materialni obrat" v družbenih vedah. Nekaj podobnega predlaga Morley (2007) v zvezi s televizijo in Rice (1999) z računalniško komunikacijo. Morley meni, da bi se televizijske študije morale lotiti denaturalizacije televizije kot fizičnega objekta ter proučevanja medsebojne povezanosti televizijske škatle (oz. danes že plošče) in mikrogeografije doma, ki je v drugi polovici 20. stoletja prispevala $\mathrm{k}$ preoblikovanju arhitekture doma. Zgodovinski razvoj televizije in doma sta namreč tesno povezana. Tradicija proučevanja televizije je zaradi svojega osredotočenja na televizijske vsebine, estetske oblike in družbene učinke le-teh popolnoma spregledalo fizično prezenco televizije kot materialnega objekta ali kot "totemskega elementa pohištva" (str. 278), ki je po njegovem osrednjega pomena za sodobni koncept doma. Rice $(1999,27)$ pa v razpravi o novih medijih meni, da je za raziskovanje družbene vloge novih medijev ključno ravno preiskovanje njihove 
"artefaktne" narave. Telefon in drugi tehnični artefakti namreč niso le tehnična orodja, temveč konstituirajo referenčni okvir našega izkustva. ${ }^{3}$

\section{Artefaktnost telefona}

Tako kot televizija je tudi telefon glasovni, pisni in sedaj tudi vizualni komunikacijski medij, obenem pa je tudi "stvar", fizična materialnost, ki ima poleg uporabnih komunikacijskih funkcij in simbolnega (totemskega) pomena, tudi "protetično" vlogo, torej razširjanje senzoričnih zmožnosti telesa. Ta vloga mobilnega telefona je v obstoječi literaturi zadnjih deset let večinoma zapostavljena, predmetnost telefona pa zreducirana na njegov simbolni vidik. Totemizem in animizem sta v tradicionalni družbi torej postopka "oživitve" in personalizacije objektov. Pri totemizmu predmet ali žival postane simbol skupnosti ali klana in je zato obravnavan na poseben način (ni je na primer mogoče jesti), animizem pa pomeni podeljevanje posebnega pomena objektom, ki dobijo zmožnosti delovanja, voljo in namernost, skratka vlogo družbenih akterjev. Čeprav pojem totema tu uporabljamo zgolj metaforično, menimo, da ima materialna kultura visokega kapitalizma, za katero je značilna praksa sistematičnega simbolnega opremljanja množično proizvedenih produktov s pomenom, več skupnega z odnosom do materialnega sveta v tradicionalnih skupnostih, kot predpostavlja kritika "potrošniške družbe". ${ }^{5}$ Te kritike pri tem pogosto izhajajo iz vnaprejšnje predpostavke o radikalni različnosti moderne družbe ter industrijskega postopka personalizacije proizvodov skozi industrijo oglaševanja in druge promocijske diskurze, od odnosa do objektov v tradicionalnih družbah in enostavnih skupnostih. Način simbolizacije in opremljanje stvari s pomenom je $\mathrm{v}$ moderni družbi res industrializiran ekspertni postopek (skozi industrijo oblikovanja ter industrijo oglaševanja, promocije in publicitete), medtem ko v tradicionalnih družbah izhaja iz religije in tradicionalne kozmologije. Toda s fenomenološkega stališča je moderna kultura znamčenja in narativizacije industrijskih objektov kot blagovnih znamk tesno povezana s univerzalno prakso antropomorfologizacije objektov, torej oživitve neživih objektov v vseh človeških družbah. Chris Gosden (2006, 425-442) meni, da je rigidno “zahodnjaško” ločevanje med živimi bitji z voljo, namero in sposobnostjo smiselnega delovanja ter neživimi stvarmi historično nekaj posebnega in verjetno že del procesa objektifikacije kot rezultata kapitalistične množične proizvodnje in potrošnje.

Kljub dramatičnemu učinku industrializacije in kljub dramatičnemu posegu novih tehnologij $\mathrm{v}$ vsakdanje življenje $\mathrm{v}$ zadnjih dvajsetih letih ter njenemu učinkovanju na preoblikovanje družbe in človeške interakcije s stvarmi, so družbene vede na splošno malo zainteresirane za materialne artefakte in so se le ob robu lotevale odnosa med objekti in ljudmi, družbo in tehnologijo in kulturo in naravo. ${ }^{6}$ Materialne stvari so za družbene vede bodisi v celoti zunanje okolje ali objektivni svet bodisi simbolna artikulacija družbenih razmerij. Tako materialnost včasih ostaja okolje zunaj subjekta, drugič ljudje stopajo v interakcijo z ločenimimi objekti, ali pa se materialne objekte uporablja kot orodja, ki povečajo človeško instrumentalnost, torej kot akterjev podaljšek. Za analizo modernih družbenih razmerij je svet objektov še bolj pomemben kot nekdaj, saj se ljudje zaradi individualizacije še bolj povežejo z objektnimi svetovi. Sodobno individualizacijo in deobjektivizacijo identitet, torej ločevanje individualnih identitet od kolektivnih, je spremljala ekspanzija "objektno osrediščenih okolij" (Knorr-Cetina 1997, 1), ki umeščajo in stabilizirajo sebstva, 
definirajo individualne identitete in skupnosti ter promovirajo oblike družbenosti, ki dopolnjujejo človeške oblike družbenosti, ki se jim sicer družboslovci bolj posvečajo. Knorr-Cetina za te trende predlaga uporabo pojma "objektualizacije" ali "objektno osrediščene družbenosti". Določene oblike odnosov z objekti in skozi objekte so bile seveda vedno značilne za človeka, toda te interakcije po njenem $\mathrm{v}$ sodobni družbi naraščajo in koncept družbenega bi jih moral vključiti. Prosti čas, na primer, je posebej bogato področje za analizo družbenosti z objekti, za ugotavljanje razlike med različnimi tipi družbenosti z objekti in skozi objekte. Družbene vede se tako v glavnem na dva načina ukvarjajo z objektnim svetom: prvič, tako da značilnosti objektov razumejo kot metaforo družbenih odnosov, lotevajo se torej njihove reprezentacijske ali simbolne vloge. In drugič, razmerja med materialnostjo in družbenostjo se lotevajo skozi načelno teoretsko razpravo o družbenih dimenzijah materialnih oblik in materialnih dimenzijah družbenosti. Tako en kot drug pristop imata dolgo tradicijo. Skoraj v celoti pa se izognejo študiju t. i. performativne vloge materialnih objektov, predvsem $\mathrm{v}$ praksah uporabe in potrošnje.

Predpostavka, da ideje, vrednote in družbeni odnosi ne obstajajo pred kulturnimi oblikami, temveč so ustvarjeni skozi proces, v katerem sami ustvarjajo materialne oblike, leži že v osnovi pojma povnanjenja ali objektifikacije, najprej pri Heglu in nato pri Marxu. Pojem objektifikacije obravnava naravo materialnosti in odgovarja na vprašanje, kako so objekti in materialne oblike vpete $\mathrm{v}$ življenjske svetove posameznikov, skupin, institucij, kulture in družbe ter kaj stvari pomenijo ali počno v družbenem svetu. Poskuša preseči dualizem modernega empiricizma, ki na objekte in stvari gleda kot na entitete, ki so v protislovju s človeško naravo družbe, torej preseči dualizem med človeškim in nečloveškim, med aktivnim in pasivnim. Skozi ustvarjanje, uporabo, izmenjavo, simbolizacijo, potrošnjo, interakcijo in življenje s stvarmi, se ljudje v procesu uporabe stvari konstituirajo. Objektni svet je tako zares osrednjega pomena za razumevanje subjektivitet in identitet individualnih ljudi in družb. Na kratko, pojem pomeni oblikovanje subjekta skozi ustvarjanje zunanjega sveta ali njegovo projekcijo na zunanji svet (materialna kultura, jezik, institucije ali koncepti, kot sta narod ali religija) in posledično introjekcijo teh projekcij. Naše stvari, artefakti, ki jih zapustimo, po smrti objektificirajo naš pretekli obstoj, hiše npr. so objektifikacije, ki služijo za posameznikovo in skupinsko védenje o sebi. V tej perspektivi je objekt konkretno utelešenje ideje, ideja, ki postane realizirana $\mathrm{v}$ obliki materialnih stvari.

Miller (1987) preiskuje filozofske izvore pojma povnanjenja pri obeh in ga vzpostavi kot ključni koncept svoje analize potrošne materialne kulture v kapitalizmu. Najsplošneje koncept povnanjenja poskuša doseči odpravo dualizma med subjektom in objektom: dobrine so neposredno konstitutivne za naše samorazumevanje in za razumevanje drugih, tako da ni nobene osnovne ločitve med človeškostjo in materialnostjo. Naša človeškost torej ne obstaja pred tem, kar ustvarja. Pojem povnanjenja torej na kratko pomeni, da se subjekt oblikuje skozi ustvarjanje zunanjega sveta ali projicira ta zunanji svet nase skozi materialno kulturo, jezik, institucije, kot sta narod ali religija itd., kar posledično privede do ponotranjenja (introjekcije) teh projekcij. $Z$ ustvarjanjem, uporabo, izmenjavo, potrošnjo ... in nasploh v življenju s stvarmi se ljudje šele konstituirajo. Miller $(1987,215)$ pravi, da "množično blago predstavlja kulturo, ne zato ker predstavlja okolje, v katerem delujemo, temveč ker je integralni del procesa povnanjenja, s katerim se ustvarjamo 
kot industrijska družba: naše identitete, naše družbene pripadnosti, naše vsakdanje prakse". Marx in Hegel umestita objektifikacijo kot časovni trenutek v širši dialektični proces - objektifikacija je implicirana v delovanju, v fizični proizvodnji stvari, ki so same aktivne v samokonstituciji identitet in interakcije med ljudmi. Kot vidimo, se razmerje med materialno kulturo in družbo tu ustvarja v procesu proizvodnje materialnega sveta. Toda, kot pravi Miller, stvari niso le objektifikacije $\mathrm{v}$ trenutku njihove proizvodnje, temveč skozi njihov celoten življenjski cikel - v trenutku izmenjave, prisvajanja in potrošnje . Objekti so del človeškega delovanja in lahko proizvajajo nove vrste delovanja, objektov in dogodkov.

Z drugimi besedami, brez stvari, zunaj materialne kulture ni človeške družbe, saj je materialna kultura od kulture in človeške družbe absolutno neločljiva in zanjo konstitutivna. Kultura in materialna kultura sta dve strani istega kovanca, sta $\mathrm{v}$ dialektičnem odnosu in v stalnem procesu nastajanja. Osebe in stvari so v dinamičnem odnosu, ta odnos pa je konstitutiven za človeško kulturo, za specifične družbe in skupnosti ter za individualno in skupinsko delovanje. Ideje, vrednote in družbeni odnosi ne obstajajo pred kulturnimi oblikami. Toda vse to ni nič novega, za družbeno teorijo povezanost med družbenim in materialnim načelno ni problematična in obstaja vrsta humanističnih in družbenih ved, ki uporabljajo materialne objekte, da bi sklepale o naravi človeških družb. Materialni objekti so tu razumljeni kot opredmetenje idej človeške kulture in refleksije družbenih razmerij, torej neke vrste eksternalizacija eksternalizacije nas samih, ki naj bi odražala nekaj bolj temeljnega v naši zavesti ali v družbenih odnosih. Stvari pa niso le pasivne refleksije družbenih odnosov, temveč so ti odnosi ustvarjani skozi postopke in procese, v katerih te oblike same nastajajo. Materialne oblike zato ne zrcalijo le že vnaprej obstoječih družbenih razlik, idej in simbolnih sistemov. Stvari so medij, skozi katerega se te vrednote, ideje ali družbene razlike stalno reproducirajo, legitimizirajo in preoblikujejo. Različne oblike družbenosti in različni načini konstrukcije identitete se proizvajajo s posredništvom materialne kulture. Osebna in družbena ter kulturna identiteta je utelešena v nas samih, obenem pa objektificirana v naših stvareh. Ali, metaforično rečemo, dotikamo se stvari in stvari se dotikajo nas. Gre za recipročni odnos. Skupaj z diskurzivnimi in političnimi odnosi med ljudmi, ki so sicer konvencionalno domena družbenih ved, naše interakcije s stvarmi manifestirajo in obenem konstituirajo kulturo družbe, v kateri živimo.

Foucault $(1991,111)$ na primer razlikuje tri vidike človeškega delovanja, to je načina izvrševanja oblasti. To so trije modusi objektivacije, ki ljudi preobrazijo v subjekte: prvi način izvrševanja oblasti je oblast nad stvarmi, to je objektivna zmožnost ali smotrno delovanje. Tu gre za rokovanje s stvarmi, ki jih uporabljamo, konzumiramo, uničujemo. Tu oblast izhaja iz "spretnosti, neposredno inherentnih telesu, ali kot jo prenašajo zunanji instrumenti." Drugič, gre za razmerja moči, ki vključujejo naše vladanje drugim ali izvajanje oblasti nad nami. Tretji način izvrševanje oblasti pa so komunikativni odnosi, ki zadevajo prenos pomena in informacij s pomočjo jezika ali drugega simbolnega medija, s čimer tudi delujemo na drugo osebo. Čeprav so ti trije vidiki konceptualno ločeni, so na empirični ravni prepleteni, se prekrivajo in medsebojno podpirajo in uporabljajo en drugega za neki smoter: oblastna razmerja, na primer, vedno potekajo skozi objektivne zmožnosti, saj je odnos med posameznikom in družbenim redom vedno že artikuliran v našem rokovanju z materialno kulturo, po drugi strani pa komunikacijska razmerja 
vključujejo objektivne zmožnosti, to je smotrne dejavnosti. Skratka, rokovanje z materialno kulturo je načelno in teoretsko pripoznano kot ključni element razmerij moči v družbi.

\section{Metaforična in protetična vloga objektov}

Po drugi strani arheologija, etnologija, antropologija, kasneje pa sociologija kulture, kulturne študije (predvsem pri proučevanju subkultur in njenih simbolnih objektov) in študije potrošne kulture oz. sodobne materialne kulture, tradicionalno uporabljajo materialne artefakte, da bi iz njihovih uporabnih, družbenih in estetskih funkcij sklepale o družbi, ki jih je ustvarila. ${ }^{7}$ Stvari so konceptualizirane kot reprezentanti družbenih razmerij, torej predvsem v svoji simbolni funkciji. Gre za konceptualizacijo materialnega objekta kot metafore realnih razmerij. Čeprav skozi metaforo ljudje lahko reflektirajo in interpretirajo svet $\mathrm{v}$ svoji materialni praksi, pa objekti niso pojmovani kot inherentni del njihove družbenosti, tako da so družbene samo kot "nosilci" zunanjih sporočil (npr. kot v materialnost vpisano védenje) sama njihova "objektnost" pa je na splošno zapostavljena. Očitno je torej, da tako $\mathrm{v}$ družbenih vedah kot $\mathrm{v}$ humanistiki, kjer se ukvarjajo $\mathrm{z}$ objekti, prevladuje lingvistična analiza pomena objektov, ki razume objekte kot reprezentacije nečesa zunaj njih, na račun analize njihove performativne sposobnosti, ki izhaja iz njihove materialnosti. Družbenost fizičnih objektov je tako sicer pripoznana in večina se načelno strinja, da se "subjekt družbenega delovanja konstituira na podlagi materialnih in kulturnih odnosov" (Dant 2005, 5). Toda odnos med objektnim in družbenim svetom je zreduciran na semiotske dimenzije objektov, torej bolj ali manj trdnem konsenzu ali pogajanju glede pomena stvari ali pa ostaja vpliv materialnosti na interakcijo in proces uprizarjanja načelno pripoznan, toda empirično nerešen. ${ }^{8}$ Proučevalci mobilne telefonije se sicer zavedajo objektne narave telefona in jo omenjajo, proučevanje tega vidika telefonije pa kljub temu ostaja omejeno na njegovo vlogo simboliziranja - modernosti, stila, statusa ali razreda. ${ }^{9}$

Razumljivo, da je klic po performativni, protetični obravnavi stvari izšel iz sociologije tehnologije in znanosti, saj si je današnje tehnologijo in objekte, ki jo zastopajo, lažje zamišljati kot "žive" in dejavne ter povezane s človeškim svetom. Tudi za McLuhana (1994) avtomobil kot ekstenzija človeškega telesa ni tako pomemben kot označevalec, ki simbolizira npr. spolne identitete ali družbeni status, temveč njegova moč kot "vročega, eksplozivnega medija" družbenega komuniciranja, ki lahko premika ljudi naokrog mnogo hitreje kot kočija ali peščeve noge. ${ }^{10}$ Materialne oblike niso pomembne zgolj zato, ker materializirajo koncepte (torej zaradi svoje reprezentacijske funkcije), temveč jih soustvarjajo s tem, ko povezujejo naturalizirane in ritualizirane veščine telesa $\mathrm{z}$ mentalnimi reprezentacijami. Antropolog Schiffer (1992) se zavzema za proučevanje interakcije med ljudmi in objekti, ker, po njegovem, "človeško življenje sestoji iz nenehnih in raznovrstnih interakcij med ljudmi in različnimi stvarmi" $(1992,2)$. Rokovanje z objekti je po njegovem komuniciranje med ljudmi, ki pa vključuje materialne artefakte. Knjiga, na primer, je tako simbolna entiteta in kulturni artefakt, toda tudi materialni objekt, ki je konstitutivni del "bralne situacije", zgodovinsko spreminjajočih se bralnih ritualov, telesnih poz ob branju in predpisanih ali tipičnih prostorov in situacij branja glede na tiho ali glasno branje, posebne drže telesa in razmerja do prostora. ${ }^{11}$ Podobno velja za mobilni telefon, televizijo, računalnik, kos obleke ali avto. Materialne kulture torej ne 
moremo obravnavati zgolj kot tiste, ki reificira v materialnem mediju tisto, o čemer je mogoče komunicirati tudi z besedami. Neverbalna ali nediskurzivna materialnost (ki presega njeno tehnofunkcijo) je torej izjemno pomembna in materialne stvari gre razumeti kot aktivne v proizvodnji družbenega reda, ne zgolj kot popredmetenje družbenega reda. Stvari so "vozlišča družbeno sankcioniranega vedenja" (Preda 1999,348 ) in oblikujejo časovne strukture ter omogočajo stabilizacijo in reprodukcijo družbenega reda, ne le zaradi simboliziranja družbenih odnosov, temveč zaradi materialnosti same. To pomeni, da o družbenem redu ne moremo razmišljati le kot o mreži intersubjektivnih odnosov, temveč tudi kot o mreži objektnih odnosov.

Preseganje lingvistične analize in razumevanja materialnih objektov le kot simbolnih nosilcev družbenih razmerij ter poudarjanje performativne vloge materialnosti razlikuje "reprezentativne" pristope od t. i. "novih materializmov". Vse od devetdesetih let so v družbenih vedah namreč vse bolj glasni pristopi, ki kličejo po bolj intenzivnem ukvarjanju z razmerjem med materialnostjo in družbo. ${ }^{12} \mathrm{Te}$ pristope srečamo predvsem znotraj sociologije znanosti in znanja ter na področju proučevanja tehnologij, $\mathrm{v}$ humanistiki pa $\mathrm{v}$ antropologiji in arheologiji. Vrsto perspektiv, ki bi jih lahko združili pod imenom "novi materializmi", druži večja občutljivost za performativno in integrativno zmožnost objektov ali stvari v konstituiranju družbe in družbenosti. Sociologija materialnosti oz. različne smeri, ki bi jih lahko združili pod tem imenom, izhaja iz predpostavke, da je družbenost "objektnosrediščna" (angl. things-centered). Njena objektnost se kaže v naslednjem: konstitucija družbenega reda se odvija skozi in na podlagi stvari, oblikujejo se artefaktno določene nove časovne strukture, ki omogočajo stabilizacijo in reprodukcijo družbenega reda ter oblike družbene moči, ki jih omogočajo in sprožajo stvari. Človeška refleksivna praksa izhaja iz vsakdanje skrbi za objekte, iz vsakdanjega brkljanja okoli objektov in z objekti in iz odgovorov in reakcij na tiste izzive, ki jih prinašajo stvari (Preda 1999, 349).

Warnier $(2001,21)$ meni, da materialnih objektov in telesnih tehnik ne moremo reducirati na enostavno družbeno logiko, kjer pripadnost neki kulturi določa, v kakšnem odnosu smo do objekta. Tehnike telesa praviloma vedno inkorporirajo materialne objekte. Zgolj diskurzivna analiza pomena objektov ni dovolj za razumevanje materialnih praks in ob analizi diskurzivnih in emocionalnih odnosov do objektov, potrebujemo tudi "prakseologijo" dejanske uporabe objektov. Treba je preiskovati utelešene prakse v človeški kulturi, da bi razumeli, kako se ob nastajanju različnih subjektivitet $\mathrm{v}$ dani kulturi vzpostavlja odnos med človekovimi praksami in specifičnimi objekti. Warnier se zato ukvarja s subjektivizacijo objektov, ne na interakcijo med objekti in subjekti, njegovo raziskovanje pa je osredotočeno na vprašanje, kako je subjektiviteta poudarjena, ko materialne oblike podaljšajo in razširijo mogoče oblike delovanja človeškega telesa. Materialni objekti so "recipienti telesnih praks" (Dant 2005, 5) in materialne oblike razširijo možnost delovanja človeškega telesa. Telefon, tako kot drugi objekti, ki so inkorporirani skozi človekove telesne tehnike, podaljšuje telo in postane njegov senzorični organ. ${ }^{13}$ Eden od razlogov za zapostavljenost performativne vloge objektov je gotovo naturalizacija "telesnih tehnik". Telesne tehnike in materialno orodje so del kulture, ki oblikuje delovanje, ki se zdi v celoti naturalizirano. M. Mauss pravi (1996, 201-226), da človek tehnično dejanje, ki ga izvršuje, občuti kot dejanje, ki sodi na področje mehaničnega, fizičnega ali fizično kemičnega, vključno s smotrom dejanja, ne pa 
kot družbeno in kulturno dejanje. Preiskovanje utelešenega odnosa z materialnim in inkorporiranje objektov skozi telesne tehnike bi moralo dopolniti obširno preiskovanje zmožnosti materialnih objektov da reprezentirajo družbene odnose. Kaj protetična vloga objektov v resnici pomeni? Proteza ali protetika je dobesedno umeten del telesa (umetnik kolki, umetni udi, zobje), ki nadomešča manjkajoči ali nedelujoči organski del telesa. Telefon, pa tudi druga raznovrstna prenosna orodja, dopolnjuje fiziološke sposobnosti telesa in soobstaja skupaj z njim. V novejši družbeni teoriji, ki se ukvarja z interakcijo med telesom in tehnologijo, se uporablja poimenovanje protetična kultura, protetični spomin ali protetična identiteta, da bi opisali nadomeščanje telesa $\mathrm{z}$ različnimi orodji in torej tudi razširjanje senzoričnih kapacitet telesa (Shilling 2005, 175). Velika moč in vpliv tehnologije je v oblikovanju objektov, ki "podaljšujejo" utelešenega akterja kot nosilca delovanja, ne pa kot samostojnih objektov, ki bi delovali v imenu akterjev. Protetično naravo objektov dopolnjuje njihova vključitev v našo individualno identiteto in čut sebstva. Odrasli imajo vrsto tranzicijskih objektov (Dant 2005, 62), ki ponujajo most med notranjim psihičnim življenjem in zunanjim družbenim svetom. Psihično življenje se prenaša na objekte, ki služijo kot sredstvo izražanja emocij. Čiščenje in uporaba orodja za čiščenje je tako lahko eksternalizacija emocij, sproščanje in obenem spopadanje s psihičnimi tenzijami. Tisseron poudarja emocionalni odnos in rokovanje z objekti in postavi pod vprašaj poudarjanje simbolnega pomena objektov, reduciranje objekte na znake, ki je dominantno v družboslovju. Objekti ne posredujejo med družbo in posameznikom le skozi lingvistično simboliko, temveč skozi delanje ali izbiranje objekta ter skozi tehnike in prakse uporabe (Tisseron v Dant 2005, 65). Objekti so kot posredniki med posameznikom in družbo vključeni v posameznikovo delovanja, ki je hkrati simbolno in psihološko signifikantno, tako da je vsak akt esteriorizacije tudi akt interiorizacije, simbolizacija v materialnem svetu pa je tako družbena kot psihična, kolektivna in hkrati osebna. Objekti tako niso le ekstenzija naše motorike ali čutnih organov, temveč ekstenzija našega uma. $V$ tem smislu Gell (2002) govori o "premeščeni osebi" (angl. distributed person) ${ }^{14}$. Posameznikovo delovanje je lahko distribuirano, preusmerjeno, premeščeno v vrsto objektov. Prek premeščanja delovanje lahko obstaja tudi v materialnih objektih, kar velja tako za tradicionalne kot za moderne kulture.

\section{Živost stvari}

"Materialni obrat" pomeni hkrati tudi premik v razmišljanju, na kakšen način prihaja do družbene integracije in do spremembe v razmišljanja o družbenem učinku materialnih objektov, ki bi preseglo predpostavko, da so stvari pomembne toliko, v kolikor so "napolnjene" z družbenim, torej le simbolizirajoč družbena razmerja, in nas torej zanimajo zgolj v svoji simbolni dimenziji. Dolgo obstoječa dvojnost, "véliki razcep" med družbenim in materialnim, med besedo in svetom, med resničnim in družbenim, med strukturo in delovanjem, med družbenostjo in materialnostjo je torej postavljeno pod vprašaj. Pomik od poststrukturalističnega in konstruktivističnega poudarka na tekstualnosti in diskurzivnosti k materialnosti naj bi odprl nova vprašanja, ki bi pomagala pojasniti človeško družbo. Razcep med družbenim in materialnim je najbolj dosledno kritiziran in teoretsko presežen pri t. i. "actor-network theory" (pogosto krajše poimenovani ANT) v sociologiji znanosti in znanja (npr. Latour, Callon, Knorr-Cetina, Law). Sociologija znanosti 
in tehnologije je najbolj radikalno pokazala, kako lahko tehnologijo v resnici razumemo kot nadaljevanje politike $\mathrm{z}$ drugimi sredstvi. So neke vrste v materialnih objektih "odrevenela družbena razmerja" (Woolgar 2005 29-30). Ne le zato, ker metaforično simbolizirajo družbeno, temveč ker utelešajo možnosti delovanja in odnosov. ANT izhaja iz tehnološkega konstruktivizma, ki znanstveno odkritje razume kot proces družbene konstrukcije in poudarja po eni strani vlogo družbenih razmerij v nastanku novih tehnologij, po drugi strani pa tudi moč naključja. ANT temelji na predpostavki o delujoči naravi nečloveškega, objektnega, materialnega sveta in predpostavlja, da je večina družbenih razmerij hkrati materialna (med stvarmi) in semiotska (med ljudmi in njihovimi idejami, koncepti), ohranjanje teh razmerij pa poteka prek stalnega uprizarjanja.

Stališče, da ima tehnologija neodvisno vzročno vlogo v proizvodnji družbenih oblik, praks in razmerij, je na načelni ravni danes v celoti zavrnjena, čeprav pogosto molče prisotna kot neizgovorjena predpostavka raziskovanja ali komentiranja. Tehnologije so tako razumljene kot vpete v politični, kulturni in ekonomski kontekst, ki oblikuje raziskovanje in razvoj ter preoblikovanje tehnologij v tehnološke produkte. Skrajni družbenokonstruktivistični pogled pravi, da so inovacije novih tehnologij v celoti funkcija družbene interpretacije in so torej "tekstualno" konstruirane. ${ }^{15}$ Feenberg $(1999,88)$, ki se ukvarja z zgodovino in sociologijo tehnologije, govori o "tehnološkem kodu", da bi opisal ujemanje tehnoloških inovacij z družbenimi interesi. Tehnični kod obsega tako sam objekt kot njegove družbene pomene. Za primer daje tekoči trak, ki spoji tehnologijo in kulturo, da bi dosegel tako funkcionalne učinke povečanja proizvodnje in hkrati uveljavi družbeno moč, torej nadzor nad delavci. Njegov argument je, da so tehnološki izumi in odkritja res nevtralni sami po sebi, vendar pa uporabljeni v družbenem kontekstu (in vedno so uporabljeni v družbenem kontekstu), oblikujejo posebno konfiguracijo, skozi katero se uveljavljajo razmerja moči. Pri tem razlikuje primarno in sekundarno instrumentalizacijo tehnologije (str. 202). Primarna instrumentalizacija vključuje aplikacijo tehnološke racionalnosti za razvoj novih tehnologij. Sekundarna instumentalizacija pa je bolj praktični nivo vključevanja novih tehnologij v materialno življenje družbe. Ravno na tej sekundarni ravni politika oblikuje vključevanje tehnologij v družbo. Ko so tehnologije oblikovane na primarni ravni, ni več mogoče zavrteti kolesa nazaj, toda načina njihovega preoblikovanja ne določajo tehnološki imperativi. Iz tega je mogoče razbrati, da se politična reinterpretacija tehnologije lahko vključi šele na nivoju uporabe, potrošnje in adaptacije tehnologije, ne pa na nivoju razvoja novih tehnoloških oblik. Tehnični kod je utrjen, ko se začne specifična tehnologija načrtno razvijati, ker se ujema z družbenimi zahtevami: dober primer je razvoj avta na bencin, kjer so hegemonični interesi podpirali razvoj te tehnologije na račun električnega avta. Politični učinki kulturnih protislovij so del tehnološkega razvoja. Tehnologija tako seveda lahko podpira kapitalistično hegemonijo, toda hkrati tudi njeno subverzijo - vsaka tehnologija, ki povečuje komuniciranje med ljudmi, ima po njegovem potencialno demokratični potencial. Na sekundarnem nivoju torej pride do nekakšnega procesa konkretizacije tehnologije in tu se tehnologija v celoti vključi v sistem visokega kapitalizma. ${ }^{16}$ Uporaba tehnologije (skupaj z njenimi družbenimi posledicami) ni že vnaprej vpisana v tehnološko inovacijo, čeprav je omejena $\mathrm{z}$ inherentnimi značilnostmi tehnologije.

ANT je, naslanjajoč se na konstruktivistično tradicijo v pogledu na tehnologijo, pomaknila pozornost na materialne artefakte, katerih delovanje je $\mathrm{v}$ mreži ak- 
terjev pogosto tako pomembno kot delovanje človeških akterjev. Vsak artefakt torej uteleša specifično védenje. Treba pa je seveda upoštevati, da imajo objekti inherentne snovne omejitve, torej omejujoče lastnosti materialnega, ki omejujejo možnost njihove družbenosti. Tehnološki objekti, ki jih uporabljamo in ki kreirajo del našega kulturnega izkustva, imajo namreč tudi neodvisne materialno inherentne značilnosti, ki pogojujejo možnosti in interpretacije uporabe. Različne tehnologije imajo tako različne danosti in te danosti omejujejo načine mogočega "branja"/uporabe tehnologije. Toda res je tudi, da je danost lahko vtisnjena v objekt z oblikovanjem v proizvodnji, torej bi jo lahko razumeli tudi kot rezultat pripisovanja pomena in funkcije objektu $v$ družbenem in ne le $v$ fizičnem svetu. ANT-pristop na splošno tematizira delovanje materialnega sveta in razmerje med človeškim delovanjem in materialnim delovanjem. Tehnologija ni ločena stvar z interno logiko, ki določa delovanje tehnologije, temvečje preplet materialnega in družbenega, ki proizvajajo vzorce delovanja, ki so tako materialni kot družbeni. Stvari torej lahko razumemo kot akterje, ne zgolj kot pasivne objekte. Nečloveški akterji, ki delujejo, kot bi bila v njihovo delovanje vključena namera, volja, se mešajo s človeškimi in tako oblikujejo mrežo. Materialni objekti postanejo nosilci družbenih pravil, ki so aplicirana na ljudi in na ta način posegajo $\mathrm{v}$ odnose moči ter nadzorujejo védenje in družbene prakse. To delovanje seveda ni primerljivo z refleksivno zavestjo, ki je značilna za ljudi. Objekti imajo vlogo akterja, toda njihovo delovanje izhaja iz človeškega delovanja, ki jih oblikuje, uporablja. Ali, kot pravi Dant $(2005,60)$, delovanje objektov je v resnici človeško delovanje, preneseno na materialne objekte.

\section{Mobilni telefon $v$ Sloveniji}

Članki, zbrani v tej številki Javnosti so prispevek k teoretski obravnavi telefona kot kulturnega artefakta in telefoniranja kot kulturne prakse, obenem pa prinašajo pomembno etnografsko gradivo o uporabi telefona in posledicah te uporabe. ${ }^{17} \mathrm{~V}$ luči pomanjkanja kulturnozgodovinskih analiz uporabe medijev pri nas je izjemno dragocen prispevek Maruše Pušnik, ki na osnovi vrste virov (statistični podatki, časopisi, spomini uporabnikov) analiza razvoj in raba fiksne in mobilne telefonije v Sloveniji v 20. stoletju in oblikovanje specifične telefonske kulture. Telefon obravnava hkrati kot tehnični aparat, kot družbeno institucijo in kulturni produkt. Obravnavo sodobne telefonske kulture umesti v kontekst zgodovine tehnoloških inovacij in kulturnih sprememb, ki so telefon omogočile, ali jih je telefon pomagal oblikovati. Članek sledi prihodu fiksnega telefona v Slovenijo konec 19. stoletja in rabo telefonske tehnologije proučuje $\mathrm{v}$ dveh obdobjih: obdobje javne uporabe telefona, ki ga zaznamujejo telefonske govorilnice in "funkcionalna" uporaba telefona, ter doba zasebne rabe telefona nekje do osemdesetih let, ki se zaključi z razširitvijo mobilnega telefona v osebni aparat in podaljšek telesa, ko leta 2003 mobilni telefonski promet preseže telefonski promet $\mathrm{v}$ fiksni telefoniji. Avtorica nas vseskozi spominja, da telefona ni mogoče obravnavati le kot tehnični aparat, temveč kot kulturni produkt, saj je spremenil dojemanje prostora, sociabilnosti in časa.

Mojca Pajnik v tej številki Javnosti predstavi prepričljivo kritiko učinkov mobilne telefonije na javni prostor ter kritiko komercialnih diskurzov, ki mobilno telefonijo uokvirjajo in pri tem promovirajo potrošniško stilizirano uporabo mobilnih telefonov. Oglaševanje, ki promovira mobilno telefonijo od sredine 90 . let, združuje promocijo tehnoloških inovacij, uporabno vrednost telefonov, s simboliziranim 
predstavljanjem vizualne podobe aparatov in simbolno produkcijo pomenov. Avtorica v nasprotju z neoliberalno retoriko o demokratizaciji sveta s telekomunikacijskimi možnostmi meni, da sam tehnološki razvoj ni povezan z demokratizacijo javne sfere, saj ta retorika zanemari tudi posledice te tehnologije, kot je npr. izginjanja kulture pisem in medosebnega komuniciranja Članek obravnava spremembe javnega prostora pod vplivom mobilnega telefoniranja kot potrošniške prakse, kjer se ta spreminja v mrežo številnih nepovezanih glasov, ki spreminjajo oblike in prakse pogovarjanja in poslušanja. Definira tri učinke te mreže glasov na prostor: prvič, vdor intimnosti v javnost. Intimnost se tu spreobrača v distanco, zasebnost pa v javno izpostavljenost. Drugič, ekscesivno subjektivizacijo in individualizacijo javnega prostora. Javni prostor ni več prostor skupnega, ampak se spreminja $\mathrm{v}$ razdrobljen sistem individualiziranih komunikacij, ki se, čeprav so prisotne v javnem prostoru, usmerjajo zunaj njega. Tretjič, vračanje teatraličnosti v javni prostor in prenovo tega prostora. Po tej, tretji intepretaciji uporaba mobilne tehnologije javni prostor spreminja v metaforični, brezmejni prostor, ki delokalizira glasove in jih poveže v nevidno mrežo odnosov na robovih družbeno-potrošniških praks.

Gregor Bulc telefon obravnava kot napravo za nadzor. Zanima ga, kako možnost stalne dostopnosti ustvarja pogoje za interpersonalno nadzorovanje na ravni vsakdanjega življenja posameznikov pri delu in v zasebnih odnosih. Naslanja se na predpostavko, da je "pogled" vedno odnos moči med gledalcem in gledanim in predstavlja torej simbolno moč, katere učinkovitost je odvisna od položaja tistega, ki opazuje/nadzoruje, in tistega, ki je opazovan/nadzorovan. Kdo je danes $\mathrm{v}$ dobi fleksibilnega trga delovne sile in prekariata kot nove zvrsti delavcev lahko nedosegljiv, kdo lahko zapira telefon? Sprašuje se, katere strukture moči in kakšna razmerja moči omogočajo ter določajo nadzorovanje posameznikove komunikacijske (ne)dostopnosti, (ne)prisotnosti, (ne)vidnosti in (ne)slišnosti v kontekstu vsakdanjega življenja. Svoje teze preverja z osemnajstimi intervjuvanci, ki so večinoma t. i. kulturni posredniki, ki nimajo več izbire tehtati med izbrano in prisilno povezanostjo v mobilno omrežje. Pobeg je za prekariat praktično nemogoč.

Članek Vlada Kotnika je nastal na podlagi obširne etnografske študije o javnih rabah mobilnega telefona v Sloveniji (na avtobusu, v bolnišnici, banki, na tržnici, v avli fakultet, bank, na mestnih avtobusih, restavracijah). Raziskava je zajela kar 564 uporabnikov mobilnih telefonov, poleg tega pa je bilo opravljenih še 17 poglobljenih intervjujev in 72 krajših poizvedb. Osrednja raziskovalna vprašanja študije so bila: Kako stalna prisotnost mobilnega telefona strukturira uporabnikov vsakdanjik in determinira posameznikovo delovanje in obnašanje na javnih mestih? Kako mobilna tehnologija določa organizacijo zasebnega in profesionalnega vsakdanjega življenja in kako uporabniki osmišljajo svoje osebne rabe mobilnega telefona? Avtor $\mathrm{v}$ teoretsko utemeljeni interpretaciji rezultatov opazovanja in intervjujev med drugim ugotavlja, da mobilna telefonija, s tem ko redefinira prostor in dosegljivost, hkrati odpravi uveljavljene ceremonialne točke telefonske družbenosti in jih razprši $\mathrm{v}$ prostorsko prostranost in nedoločenost. Po eni strani mobilni telefon bistveno povečuje možnosti izkoristka mobilnosti, intenzivira prostorsko koordinacijo ter razrešuje zagate vsakodnevne geografije, po drugi pa zagotavlja povsodnost dosegljivosti.

Andraž Petrovčič se v članku ukvarja s telefonom kot potrošnim in modnim tehnološkim artefaktom. Avtor si zada za nalogo vzpostaviti povezavo med poj- 
movanjem tehnologij kot kulturno pogojenih potrošnih praks in Campbellovim moderno hedonističnim modelom potrošnje, kjer novo ni le objektivna lastnost potrošnega objekta, temveč tudi v procesu potrošnje subjektivno umišljeno izkustvo posameznika. Svojo empirično analizo umesti v teoretični kontekst sodobnih študij potrošne družbe, ki temelji na abstraktni potrošniški želji, odvisni od "novega", inovacije in novosti, torej od stalnega nadzorovanega vnašanja novosti $\mathrm{v}$ tehnološko blago $\mathrm{z}$ namenom povečevanje potrošnje in opremljanja telefona $\mathrm{s}$ simbolnim pomenom, ki presega njegovo uporabno vrednost, da bi zadovoljili abstraktno potrošniško željo. Na empiričnih podatkih, zbranih s terensko anketo (RIS-IKT 2005), ugotavlja, kakšno vlogo igrajo modni režim, torej ideologija novega in prenovljenega ter simbolni in estetski vidiki telefona pri odločitvah o nakupu telefona ter pri "odnosu" do telefona.

\section{Opombe:}

1. Najbolj odmevne med njimi, ki so izšle v angleščini, so: Katz 2003, Fortunati, Katz in Riccini 2003, Ling 2004, Katz 2006, Horst in Miller 2006, Goggin 2006.

2. Glej tudi Bulčev članek $v$ tej številki.

3. $\vee$ tej številki Javnosti nekaj avtorjev z različnih stališč pripoznava pomen artefaktnosti telefona in njegove protetične vloge (gl. npr. Pušnik, Kotnik).

4. Edina izjema so besedila, ki se naslanjajo na koncept dvojne artikuliranosti tehnologije, ki ga je za proučevanje računalniške komunikacije razvil R. Silverstone. Tehnološka orodja, kot so na primer računalnik, avtomobil ali mobilni telefon, so, kot pravi Silverstone, dvojno artikulirana (v: Silverstone in Hirsch 1992: 21). To pomeni, da niso le fizični objekti (ki sicer nosijo simbolne pomene), temveč so tudi medij, skozi katerega se ohranja in vzpostavlja družbenost.

5. Glej tudi prepričljivo argumentacijo D. Millerja (1998, 73-110) o tradicionalnem ritualu žrtvovanja, na katerem je utemeljena današnja praksa in izkustvo nakupovanja.

6. Seveda je tu vrsta prominentnih izjem, ki načelno tematizirajo materialni svet, se pa ne ukvarjajo s prakseologijo odnosa med objektnim in človeškim svetom. (npr. Marx, Simmel, Mauss).

7. Glej npr. Celia Lury, Dick Hebdige, Arjun Appadurai, Daniel Miller, Mary Douglas in Baron Isherwood, Jean Baudrillard itd.

8. Materialne oblike so razumljene kot objektifikacija (popredmetenje) družbenih odnosov in identitet in govorijo o teh odnosih tako kot v govorici in formalnih diskurzih ni mogoče. Ravno zato ker stvari posredujejo med osebami na tihem in nezavednem nivoju diskurza, Miller (1987) govori o ponižnosti stvari (angl. humility of objects).

9. Glej npr. V. Oksman in P. Rautiainen 2002, J. E., Katz in Sugiyama 2006, G. Goggin 2006. Edina delna izjema je zbornik L. Fortunati, J. E. Katz in R. Riccini 2003. Tukajšnja kritika redukcije obravnave telefona kot artefakta na njegovo reprezentativno naravo velja tudi za našo študijo uporabe mobilnega telefona v Sloveniji. Glej B. Luthar in S. Kropivnik 2007.

10. Vprašanje je seveda tudi, ali koncepti, struktura občutenja in kozmologija obstaja pred materialnim univerzumom, tako da se abstraktne ideje materializirajo v materialni kulturi, ali pa je vzročnost obrnjena, tako da materialne oblike vzpodbujajo oblikovanje abstrakcij in reprezentacij.

11. O zgodovini branja glej Reinhard Wittmann v: G. Cavallo in R. Chartier 1999.

12. Pomembno vlogo v tej reorientaciji ima npr. tematska številka Theory, Culture and Society iz leta 2002, naslovljena Sociologija materialnosti.

13. M. Mauss $(1996,205,206)$ telesne tehnike definira preprosto kot "načine, kako znajo ljudje $\checkmark$ različnih družbah tradicionalno uporabljati telo. Pri hoji na primer je drža lahti, položaj dlani "družbena idiosinkrazija, ne pa kratko malo proizvod kdo ve kakšnih čisto individualnih povezav in mehanizmov, ki naj bi bili malone scela psihični". 
14. V slovenskem prevodu »razpršena oseba«.

15. Na nek način je skrajni tehnološki konstruktivizem, torej popolna "tekstualizacija" tehnologije kot reakcija na determinizem, le nasprotna mistifikacija tehnologije.

16. Poglejmo si npr. tehnologija mobilnega telefona, ki jo na začetku vzpodbujala le želja po neodvisnosti funkcije telefona od fiksne lokacije uporabnika, toda sproti so bile vanjo integrirane druge tehnologije (igre, ura, fotoaparat, SMS, WAP, glasbeni in video predvajalnik itd.

17. Večina prispevkov je nastala v okviru projekta Družbeni in kulturni vidiki virtualnih življenjskih stilov, ki ga financira Ministrstvo za znanost in tehnologijo.

\section{Literatura:}

Callon, Michel.1987. The Sociology in the Making: the Study of Technology as a Tool for Sociological Analysis. V: W. E. Bijker, T. P. Hughes in T. J. Pinch (ur.), The Social Construction of Technical Systems: New Directions in the Sociology and History of Technology, 83-103. Cambridge, MA: MIT Press.

Dant, Tim. 2005. Materiality and Sociality. Maidenhead: Open University Press.

Feenberg, Andrew. 1999. Questioning Technology. London: Routledge.

Fortunati, Leopoldina, James Katz, Raimonda Riccini, ur. 2003. Mediating the Human Body.

Foucault, Michel. 1991. Vednost-oblast-subjekt. Ljubljana: Krt.

Gell, Alfred. 2002. Umetnost in delovanje. Ljubljana: Študentska založba.

Goggin, Gerard. 2006. Cell Phone Culture. London: Routledge.

Gosden, Chris. 2006. Material Culture and Long-term Change. V: C. Tilley in drugi (ur.), Handbook of Material Culture, 425-442. London: Sage.

Graves-Brown, Paul M., ur. 2000. Matter, Materiality and Modern Culture. London: Routledge.

Horst A. Heather in Daniel Miller. 2006. The Cell Phone. Oxford: Berg.

Katz, E. James, ur. 2003. Machines That Become Us. New Brunswick: Transaction Publishers.

Katz E. James. 2006. Magic in the Air. New Brunswick: Transaction Publishers.

Katz E. James in Mark Aakhus, ur. 2002. Perpetual Contact. Cambridge: Cambridge University Press.

Katz, James in Satomi Sugyjama. 2006. Mobile Phones as Fashion Statements: Evidence from

Students Surveys in the US and Japan. New Media and Society 8, 321-337.

Knorr-Cetina, Karin. 1997. Socialty with Objects. Theory, Culture and Society 4, 1-30.

Latour, Bruno. 2000. The Berlin Key or How to Do Words with Things. V: P. M. Graves-Brown (ur.),

Matter, Materiality and Modern Culture, 10-21. London: Routledge

Latour, Bruno. 1993. We Have Never Been Modern. New York: Harvard University Press.

Law, John. 2002. Objects and Spaces. Theory, Culture and Society 5/6, 91-106.

Ling, Rich. 2004. The Mobile Connection. Amsterdam: Elsevier.

Luthar, Breda in Samo Kropivnik. 2007. Razred, kulturni kapital in mobilni telefon. V: V. Vehovar (ur.),

Mobilne refleksije, 55-86. Ljubljana: Založba FDV.

Mauss, Marcel. 1996. Esej o daru in drugi spisi. Ljubljana: ŠKUC/FF.

McLuhan, Marshall. 1994. Understanding Media: The Extensions of Man.

Miller, Daniel. 1987. Material Culture and Mass Consumption. Oxford: Basil Blackwell.

Morley, David. 2007. Media, Modernity and Technology. London: Routledge.

Oksman, Virpi in Pirjo Rautiainen. 2002. "Perhaps It Is a Body Part": How the Mobile Phone Became and Organic Part of the Everyday Lives of Finnish Children and Teenagers. V: J. Katz (ur.), Machines That Become Us, 293-310. New Brunswick: Transaction Publishers.

Preda, Alex. 1999. The Turn to Things: Arguments for a Sociological Theory of Things. The Sociological Quarterly 2, 347-366.

Rice, E. Ronald. 1999. Artifacts and Paradoxes in New Media. New Media \& Society 1, 24-32.

Schiffer, Michael. 1992. Technological Perspectives on Behavioral Change. Tucson: The University of Arizona Press.

Schiffer, Michael. 2000. Indigenous Theories, Scientific Theories and Product Histories. V: P. GravesBrown (ur.), Matter, Materiality and Modern Culture, 72-96. London: Routledge. 
Shilling, Chris. 2005. The Body in Culture, Technology and Society. London: Sage.

Silverstone, Richard in Eric Hirsch, ur. 1992. Consuming Technologies. London: Routledge.

Tilley, Chris in drugi, ur. 2006. Handbook of Material Culture. London: Sage.

Tomlinson, John. 2007. The Culture of Speed. London: Sage.

Warnier Jean-Pierre. 2001. A Praxaeological Approach to Subjectivation in a Material World. Journal of Material Culture 1, 5-24.

Wittman, Reinhard. 1999. Was there a Reading Revolution at the End of the Eighteenth Century? V: R. Cavallo in R. Chartier (ur.), A History of Reading in the West, 284-312. Cambridge: Polity Press.

Woolgar, Steve. 2005. Mobile Back to Front: Uncertainty and Danger in the Theory-Technology Relation. V: R. Ling in P. E. Pederson (ur.), Mobile Communications: Re-negotiation of the Social Sphere, 23-44. London: Springer. 